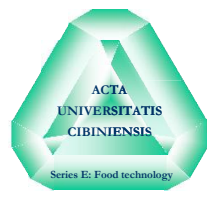

\title{
POSSIBILITIES TO DEVELOP LOW-FAT PRODUCTS: A REVIEW
}

\author{
Roxana TUFEANU ${ }^{1}$, Ovidiu TIT,A \\ Faculty of Agricultural Sciences, Food Industry and Environmental \\ Protection, University Lucian Blaga of Sibiu, Romania
}

\begin{abstract}
Research has proved a relationship between high fat consumption and rise in obesity, atherosclerosis, coronary heart diseases and high blood pressure. Therefore is recommended the moderate consumption of fat, such that the total fat does not exceed $30 \%$ of total energy intake. Our body needs fats because are providers of calories, essential fatty acids, fat-soluble vitamins and also they are necessary ingredients of the foods. The development of products with low-fat content can be considerate a challenge because the lipids offers aroma, texture, appearance, flavour and mouth feel, qualities that customers want in food products. A fat reduction can be achieved by using different fat replacers to ensure the functionality of the replaced fat. Functional components of fat replacers can have a significant role in promotion of wellbeing, in treating and preventing diseases. Thus, fat replacers should be recognized as safe and healthy, which have sensorial and functional properties. This paper reviews the fat replacers used to obtain foods as meat-based or dairy products. Some ways to obtain healthier meat products by reducing saturated fats content consist in the utilization of unsaturated vegetable oils, vegetable products, fibre. The utilization of fibre in products such bolognas, sausages or hamburgers, can improve the texture profile, binding properties and the characteristics regarding the cooking process. A fat reduction in dairy products can be achieved by replacing it with starches, polysaccharides, gums or fibres from cereal, vegetables and fruits. In acidified milk products, fibres have benefits as: low syneresis, sensory characteristics accepted by consumers, improvement of texture and rheological properties. In cheeses production, the fat reduction can be realised by replacing it with carbohydrate or protein-based replacers in order to obtain a final product with proper characteristics.
\end{abstract}

Keywords: fat, health, fat substitutes, fat mimetics

${ }^{1}$ Corresponding author. Mailing address: University "Lucian Blaga" of Sibiu, Faculty of Agricultural Sciences, Food Industry and Environmental Protection, Str. I. Raţiu 7-9, 550012 Sibiu, Romania. Phone: 0040/269/211338. Fax: 0040269212558. E-mail address: elena.tufeanu@ulbsibiu.ro, tufeanuroxana@yahoo.com 


\section{INTRODUCTION}

Foodstuffs represent important vehicles for humans, providing the essential nutrients that can maintain or improve their health (Hygreeva et al., 2014). Nowadays people are interested in foods with bioactive components which provide health benefits (Cofrades et al., 2008).

In foods, an essential component is fat with roles in development of flavour, texture, juiciness and appearance (Akin et al., 2015), (Choi et al., 2010). Lipids are also responsible in product processing for cooking yield and water holding capacity (Choi et al., 2013).

Fat provides a considerable amount of energy $(9 \mathrm{kcal} / \mathrm{g})$, is a source of essential fatty acids and is important for maintaining a healthy skin (Akoh, 1998).

Fats are vital macronutrients that keep the body healthy. Moderate fat intake is beneficial, but higher quantities of fats can determine serious complications (Siraj et al., 2015). Health organizations recommend that from total energy intake, the total fat be less than 30\% (Hooper et al., 2012), (WHO, 2003), (FAO, 2010). Also, nutritional guidelines suggest that that saturated fat should be less than $10 \%$ of caloric intake and be replaced with unsaturated and trans fats should be eliminated (WHO, 2003), (FAO, 2010), (Nishida et al., 2009).

The rise in obesity, atherosclerosis, coronary heart disease, high blood pressure is observed in recent decades because of high fat consumption (Madadlou et al., 2005). As a result, reducing fat in the daily diet has become a concern for consumers, causing an increase in the demand for reduced fat foods (Martínez-Cervera, 2011), (Chugh, 2015).

Reducing the fat content from foods causes negative impact on texture, flavour and appearance (Miles, 1996), (Romeih et al. 2002). With the aim to improve the quality characteristics of low-fat products are used fully or partially fat replacers (Akoh, 1998). They are classified as lipid substitutes and as lipid mimetics (Romeih et al. 2002). Fat substitutes can theoretically replace the fat one to one in food products (lipid- or fat-based fat replacers). Fat imitators are substances with similar properties of triglycerides, but which cannot replace fat gram-for-gram and they are called fat replacers based on proteins or carbohydrates (Romeih et al. 2002), (Akoh, 1998).

This paper reviews the ways to reduce fat content in meat products, the use of fibres as fat replacers and the ways to reduce fat content in dairy products.

\section{Ways to reduce fat content in meat products}

A healthy diet should include meat and meat products, because are important components due to their characteristics such as source of high-quality 
protein, B-group vitamins and essential fatty acids. (Biesalski, 2005), (Rodríguez-Carpena et al, 2012). After several studies regarding the connection between meat intake and higher risk of certain diseases, it could be concluded that there is a relationship between consumption of animal fats (particularly saturated fat) and increased risk of some disorders such as coronary-heart diseases and colorectal cancer (Carpena et al, 2012), (Ferguson, 2010).

Because in general in meat products the fat has high quantity of saturated fatty acids and cholesterol, in the processed meat industry the substitution of saturated fat is problematic (Hygreeva et al., 2014), (Siraj et al., 2015). Due to their fatty acid composition and lower melting temperature, saturated fats have an essential role regarding the texture, juiciness, mouth feel and general product acceptance by consumers (Siraj et al., 2015). The recommendations to increase consumption of beneficial fats, led to the production of meat products with health benefits (Hygreeva et al., 2014).

A major drawback is that meat products with reduced fat content tend to be firmer, rubberised and less succulent, with an unpleasant dark colour. Other unfavourable issues in the development of meat products with lower fat content consist in reduced cooking yields, rubbery skin formation, fat and moisture loss, which represent important qualitative characteristics for the consumers. The development of meat products with low-fat content is usually accomplished by using raw material that have the property to bind water, thus being overtaken the high dry matter content, rubberiness and being improved the juiciness (Tabarestani and Tehrani, 2014).

A way to obtain a healthier lipid content in meat products through reduce saturated fats content is the utilization of unsaturated vegetable oils, which improve the fatty acid profiles in meat products and also helps in product stability (Hygreeva et al., 2014), (Siraj et al., 2015).

Ingredients such as vegetable oils and natural extracts, vegetable products and fibre was used as in products based on meat for the improvement of functional properties (Pelser et al., 2007), (Vural, 2003), (Valencia et al, 2008), (Serdaroglu and Degirmencioglu, 2004), (Turhan et al., 2007), (Jo et al., 2003), (Turhan et al., 2005). Imaijumi et al., (2000) reported that oils rich in linoleic acid have benefits in reducing serum cholesterol levels.

Meat products with low fat content, obtained by many researchers are presented in Table 1.

\section{Fibres as fat replacers}

The diseases occurrence (gastrointestinal, obesity, diabetes, hypertension) can be reduced through consumption of dietary fibre (Anderson et al., 2009). 
Table 1. Fat replacers in healthier meat products adapted from Hygreeva et al. (2014)

\begin{tabular}{|l|l|l|}
\hline Fat replacers & Product & Reference \\
\hline $\begin{array}{l}\text { Flax seed oil } \\
\text { Canola oil }\end{array}$ & Fermented sausages & Pelser et al., 2007 \\
\hline $\begin{array}{l}\text { Palm oil } \\
\text { Cotton seed oil } \\
\text { Olive oil }\end{array}$ & Frankfurters & $\begin{array}{l}\text { Vural et al., 2002; } \\
\text { Vural et al., 2004 }\end{array}$ \\
\hline Poppy seeds & Beef burgers & Gok et al., 2011 \\
\hline $\begin{array}{l}\text { Olive oil } \\
\text { Flax seed oil } \\
\text { Fish oil } \\
\text { Konjac gel }\end{array}$ & Liver meatballs & Delgado-Pando et al., 2011 \\
\hline $\begin{array}{l}\text { Soy flour } \\
\text { Pea flour } \\
\text { Wheat starch }\end{array}$ & Hamburgers & $\begin{array}{l}\text { Tabarestani and Tehrani, } \\
2014\end{array}$ \\
\hline $\begin{array}{l}\text { Linseed oil } \\
\text { Fish oil }\end{array}$ & Raw sausages & Valencia et al., 2008 \\
\hline $\begin{array}{l}\text { Canola oil } \\
\text { Canola-olive oils }\end{array}$ & Frankfurters & Álvarez et al., 2012 \\
\hline Wallnut $(20 \%)$ & $\begin{array}{l}\text { Restructured beef } \\
\text { steaks }\end{array}$ & Serrano et al., 2005 \\
\hline Wallnut (25\%) & Frankfurters & Ayo et al., 2007 \\
\hline Wallnut paste 15,30,45\% & Turkish sucuk & Ercoskun et al., 2010 \\
\hline Olive oil 60\% & Dry, spicy sausage & Kayaardi et al., 2004 \\
\hline Lin seed oil 6.6\% & $\begin{array}{l}\text { Dry fermented } \\
\text { sausages }\end{array}$ & $\begin{array}{l}\text { Ansorena and Astiasaran, } \\
\text { 2004 }\end{array}$ \\
\hline Soy oil 15, 20,25\% & Fermented sausages & Muguerza et al., 2003 \\
\hline Olive oil emulsified alginate & Sausages & Beriain et al., 2011 \\
\hline Oat flour & Chicken nuggets & $\begin{array}{l}\text { Santhi and Kalaikannan, } \\
2011\end{array}$ \\
\hline $\begin{array}{l}\text { Fibre pectin from tomato } \\
\text { pomace }\end{array}$ & Beef burger & Namir et al., 2015 \\
\hline Cashew apple residue & Hamburgers & Pinho et al., 2010 \\
\hline
\end{tabular}

In meat products, fibres decrease the caloric content, increase the carbohydrate content and therefore may be regarded as functional ingredients (Hygreeva et al., 2014).

Plant dietary fibres have been successfully utilized as partial fat mimetics in many studies, and was concluded that utilization of fibre for obtaining meat products can improve the binding properties, textural characteristics and cooking yield (Borderías et al., 2005), (Fernandez-Ginés et al., 2004).

Choi et al. (2010) have replaced the pork fat back with grape seed oil and rice bran fibre. Their conclusion was that through utilization of these two 
replacers, besides the fact that it can reduces the amount of saturated fat, also it can improve the characteristics regarding the cooking process.

The utilization of different concentrations of lemon albedo in sausages improved the nutritional value of the final product (Fernandez-Ginés et al., 2004).

Pietrasik and Janz (2010) have produced low fat bolognas with fibre, pea starch and wheat flour. Yang et al. 2007 developed sausages with reduced fat content by adding oat meal or tofu at different concentrations and they discovered that utilization of oatmeal previously hydrated took part in increasing the water holding capacity, the cooking yield and have helped at the obtaining of a product with softer texture.

Huang et al. (2005) reported that addition of rice bran $(<10 \%)$ with different particle sizes to meatballs, may be an optimal option for obtaining products with low fat content, but a major drawback is represented by the grinding manner of the bran, because the dimension of the particles have negatively influenced the characteristics of the final product.

Garcia et al. (2002) added cereal (1.5\%) and fruit fibres (3\%) in reduced fat dry fermented sausages and observed that utilization of fruit fibre $(1.5 \%)$ along with pork fat $(10 \%)$ have led to a proper texture profile and better sensory acceptability.

Sayago-Ayerdi et al. (2009) have observed that through utilization of grape fibre improved the oxidative stability and radical scavenging activity in hamburgers obtained from chicken meat.

\section{Ways to reduce fat content in dairy products}

Currently, the tendency to consume low fat foods has grown up, even if the fat has significant impact over their physical, rheological and textural properties, microbiological stability. Thus for this purpose, to produce qualitative dairy products, are used fat mimetics, which bring a lower caloric value, ensure the same physical and sensorial characteristics in the final product (Bom Frost et al, 2001), (Jonnalagadda et al, 2005).

The production of low-fat dairy products is not an easy task. For example, acidified milk products with low fat content are harder accepted by consumers because of the undesired rheological properties and the high syneresis, while the problems at low-fat cheese are flavour and rubbery and hard texture. A fat reduction can be achieved by replacing it with carbohydrate-based fat replacers to ensure the functionality of the replaced fat. Also we can develop yoghurt by partially replacing the lipid with sodium caseinate, whey protein concentrates, or by incorporate other raw materials such as starches (Cais-Sokolinska et al., 2006), (Oh et al., 2007), (Soukoulis et al., 2007). Also, polysaccharides and gums are utilised for their properties 
to improve the texture and consistency by changing the rheological characteristics of dairy products (Everett and McLeod, 2005), (Kip et al., 2006), (Fagan et al., 2006), (Brennan and Tudorica, 2008), (Guggisberg et al., 2009). Brennan and Tudorica, 2008) have utilized dietary fibres as thickeners and stabilizers to produce sauces and dressing assortments, but they can be also added as fat replacers in a variety of products. Foods with higher fibre content offer a feeling of fullness and ensure more nutrients with few calories (Whelan et al., 2006), (Lyly et al., 2009).

Until now a series of studies have been made regarding the utilization of fibres from cereal, vegetables and fruits in yogurt (Dello Staffolo et al., 2004), (Aportela-Palacios et al., 2005), (Garcia-Perez et al., 2006), (Hashim et al., 2009), (Sendra et al., 2008), (Sendra et al., 2010). In acidified milk products, fibres have benefits as: improving texture and firmness, low syneresis and provide sensory characteristics that are accepted by consumers (McCann et al., 2011).

Brennan and Tudorica (2008) used barley beta-glucan, partially hydrolysed guar gum and inulin in the development of low-fat yogurts. For the improvement of viscoelastic nature and textural properties of the product were used $0.5 \%$ beta-glucan, and also inulin and guar gum at concentrations above $2 \%$. Analyses performed on the samples demonstrate that the utilization of these replacers could be effectively utilized to develop low fat products, by reducing the syneresis of product, the improvement of the texture and rheological properties (Brennan and Tudorica, 2008).

The utilization of natural cell wall materials in food products provides several benefits. They help maintain health and they have characteristics such as water holding capacity and rheological characteristics, which places them among the 'clean-label' ingredients in food products (Harris \& Smith, 2006). Cell wall particles are obtained from vegetables and fruits by the use of thermal and mechanical shear processes. Most often, these are obtained from by-products, with other processes conducted to minimize the particle dimension (Figuerola et al., 2005), (Chantaro et al., 2008), (Redgwell et al., 2008), (Day et al., 2010b), (Gupta and Premavalli, 2010).

Low-fat cheese varieties are usually characterized by rubbery texture, less flavour, low meltability and undesirable color (Mistry, 2001). The effects of Simplesse ${ }^{\circledR}$ D-100 and Novagel ${ }^{\mathrm{TM}}$ NC-200 (commercial hydrocolloid fat) on the characteristics of low-fat white brined cheese were investigated by Romeih et al. (2002). These fat replacers determined an increase in moisture content and cheese yield leading to an improvement of texture.

Other researchers reported that the texture of low fat Iranian white brined cheese was improved by adding gum tragacanth (Rahimi et al., 2007), or low fat paneer with superior quality were produced by incorporating $0.2 \%$ soy protein isolate as the fat replacer (Kumar et al., 2011). 
Starch is one of the most frequently ingredients used as fat mimetic, in food because it is relatively inexpensive and readily available (O'Connor and O'Brien, 2011). Waxy maize starch is a promising starch that can be considered for food applications, due to its unique composition (only traces of amylose) and its many specific attributes: easy swelling, hardly retrogrades, provides a sticky texture and offers better digestibility than do normal starches (Wang et al., 2010). The starch hidrolysates as maltodextrins are also taken into considerations as fat replacers as at the obtaining of ice cream (Roland et al., 1999): they have the advantage of possibility to obtain in a controlled way (Mironescu and Mironescu, 2011, 2012).

Totosaus and Guemes-Vera (2008) studied the role of $\kappa$ - and $\lambda$-carrageenan incorporated in low fat Oaxaca cheese, a typical pasta filata assortment of cheese (like mozzarella) (Van Hekken and Farke, 2003). The impact of introducing $\mathrm{k}$ - and $\lambda$-carrageenans in Oaxaca cheese with low fat content regarding the melting process, color, protein, moisture, and yielding was determined. The fat content affected mainly the melting, but $\mathrm{k}$-carrageenan improved this characteristic. Also, the reduction of fat content has affected the colour. It was shown that the utilization of low quantities of carrageenan has allowed the obtaining of Oaxaca cheese with significant fat reduction with an acceptable overall quality (Totosaus and Guemes-Vera, 2008).

Ertekin and Guzel-Seydim (2009) produced non-fat kefir adding Dairy Lo ${ }^{\circledR}$ and inulin, which did not have adverse effect on the properties of the product. Samples obtained with Dairy Lo ${ }^{\circledR}$ and inulin presented higher viscosity compared to the kefir produced without fat replacers. All kefir samples are identified as non-Newtonian pseudoplastic fluids with thixotropy. The conclusion of this research was that fat replacers could be added to develop milk products with low fat content, without negative effects.

Sahan et al. (2008) evaluated the quality of low-fat Kashar cheese obtained with: Simplesse ${ }^{\circledR}$ D-100, Avicel Plus ${ }^{\circledR}$ CM 2159 and $\beta$-glucan. Kashar cheese is one of the most popular cheeses in Turkey from the category of pasta-filata cheese.

Low-fat Beyaz cheeses were manufactured using as raw materials: ewe's milk, Simplesse ${ }^{\circledR}$ (protein-based replacer), Maltrin ${ }^{\circledR}$ (carbohydrate-based fat replacer) and a blend of both. The cheeses produced with Simplesse ${ }^{\circledR}$ were similar to cheese without replacers and obtained the highest sensory acceptance (Akin, 2015)

A non-fat goats' milk yogurt was obtained by adding heat-treated whey protein concentrate (HWPC) as a fat mimetic and pectin as a thickening substance. The results showed that the non-fat goats' milk yogurt made with $1.2 \%$ HWPC and $0.35 \%$ pectin presented higher viscosity compared to the other yogurts. Also this sample has registered a smaller syneresis than the yogurt obtained only with pectin. Throughout storage, viscosity and $\mathrm{pH}$ value 
of yogurt did not shown significant change. Following this research was concluded that heat-treated whey protein concentrate could be used as a fat replacer for non-fat yogurt assortments and other similar products (Zhang et al., 2015).

\section{CONCLUSIONS}

Consumer awareness of the health benefits of low-fat diets consumption is in constantly growing, but many of them are not accustomed to give up the taste, the texture and aroma in exchange of the products with health benefits. Thus, the challenge facing the food industry is to develop a variety of low-fat foods, with quality characteristics that are not impaired. Some fat replacers are important sources of bioactive components (vitamins, minerals, antioxidants) and their utilization may improve foodstuff quality and may support the food industry to achieve the objective to provide low-fat healthy products for consumers.

All research presented are intended to provide a positive image on obtaining products with low fat content and to emphasize that for developing these foodstuff should be considered a variety of factors. Further research must to be carried out in order to obtain products with health benefits, secure and shelf stable.

\section{REFERENCES}

1. Álvarez D., Xiong Y.L., Castillo M., Payne F.A., Garrido M.D., (September 2012). Textural and viscoelastic properties of pork frankfurters containing canola-olive oils, rice bran, and walnut. Meat Science, 92, 8-15. Retrieved June 2, 2015, from Science Direct database Web: http://www.sciencedirect.com. DOI:10.1016/j.meatsci.2012.03.012

2. Anderson J.W., Baird P., Davis R.H. Jr., Ferreri S., Knudtson M, Koraym A., Waters V., Williams C.L., (2009, April). Health benefits of dietary fibre. Nutrition Reviews, 67, (4), 188-205. Retrieved June 10, 2015, from Oxford Journals database Web: http://nutritionreviews.oxfordjournals.org. DOI:10.1111/j.1753-4887.2009.00189.x

3. Aportela-Palacios A., Sosa-Morales M.E., Velez-Ruiz J.F., (2005, July). Rheological and physicochemical behavior of fortified yogurt, with fiber and calcium. Journal of Texture Studies, 36 (3), 333-349. Retrieved August 28, 2015, from Wiley Online Library Web: http://onlinelibrary.wiley.com. DOI: 10.1111/j.1745-4603.2005.00020.x

4. Ayo, J., Carballo, J., Serrano, J., Olmedilla-Alonso, B., Ruiz-Capillas, C., Jiménez-Colmenero, (2007, October). Effect of total replacement of pork backfat with walnut on the nutritional profile of frankfurters. Meat Science, 77, (2), 173-181. Retrieved August 2, 2015, from Science Direct database Web: http://www.sciencedirect.com. DOI:10.1016/j.meatsci.2007.02.026 
5. Beriain M.J., Gómez I., Petri E., Insausti K., Sarriés M.V. (2011, May). The effects of olive oil emulsified alginate on the physico-chemical, sensory, microbial, and fatty acid profiles of low-salt, inulin-enriched sausages. Meat Science, 88, pp. 189-197. Retrieved June 5, 2015, from Science Direct database Web: http://www.sciencedirect.com. DOI:10.1016/j.meatsci.2010.12.024.

6. Cais-Sokolinska D., Pikul J., Wojtowski J., Dankow R. (2006). The effect of structure forming starch additives on the physicochemical and sensory properties of yoghurts. Milchwissenschaft-Milk Science International, 61 (2), pp. 173-176

7. Choi Y.S., Choi J.H., Han D.J., Kim H.Y., Lee M.A., Kim H.W., Kim C.J. (2010, January). Optimization of replacing pork back fat with grape seed oil and rice bran fiber for reduced-fat meat emulsion systems, Meat Science, 84, pp. 212-218. Retrieved June 5, 2015, from Science Direct database, Web: http://www.sciencedirect.com. DOI:10.1016/j.meatsci.2009.08.048.

8. Choi Y.S., Park K.S., Kim H.W., Hwang K.E., Song D.H., Choi M.S., Lee S.Y., Paik H.D., Kim C.J. (2013, March). Quality characteristics of reduced-fat frankfurters with pork fat replaced by sunflower seed oils and dietary fiber extracted from makgeolli lees. Meat Science, 93, (3), 652-658. Retrieved June 5, 2015, from Science Direct database,Web: http://www.sciencedirect.com.DOI:10.1016/j.meatsci.2012.11.025.

9. Cofrades S., Serrano A., Ayo J., Carballo J., Jimenez-Colmenero F. (2008, April). Characteristics of meat batters with added native and preheated defatted walnut, Food Chemistry, 107, (4), 1506-1514. Retrieved June 5, 2015, from Science Direct database, Web: http:/www.sciencedirect.com. DOI:10.1016/j.foodchem.2007.10.006.

10. Delgado-Pando G., Cofrades S., Rodríguez-Salas L., Jiménez-Colmenero F. (2011, June). A healthier oil combination and konjac gel as functional ingredients in low-fat pork liver pâté. Meat Science, 88, (2), 241-248. Retrieved March 26, 2015, from Science Direct database, Web: http://www.sciencedirect.com. DOI:10.1016/j.meatsci.2010.12.028.

11. Dello Staffolo M., Bertola N., Martino M., Bevilacqua A. (2004, March). Influence of dietary fiber addition on sensory and rheological properties of yogurt. International Dairy Journal, 14 (3), 263-268. Retrieved March 27, 2015, from Science Direct database, Web: http:/www.sciencedirect.com. DOI:10.1016/j.idairyj.2003.08.004.

12. World Health Organization. (2003). Diet, nutrition and the prevention of chronic diseases: report of a Joint WHO/FAO Expert Consultation. Geneva. WHO Technical Report Series, No. 916.

13. Ercoskun H., Demirci-Ercoskun T., Walnut as fat replacer and functional component in sucuk. (2010, October). Journal of Food Quality, 33 (5), 646659. Retrieved March 27, 2015, from Wiley Online Library, Web: http://onlinelibrary.wiley.com. DOI: 10.1111/j.1745-4557.2010.00341.x.

14. Fagan C.C., O'Donnell C.P., Cullen P.J., Brennan C.S. (2006, November). The effect of dietary fibre inclusion on milk coagulation kinetics. Journal of Food Engineering, 77 (2), 261-268. Retrieved March 27, 2015, from Science Direct 
database,

Web:

http://www.sciencedirect.com.

DOI:10.1016/j.jfoodeng.2005.06.030.

15. Food and Agriculture Organization of the United Nations. 2010. Fats and fatty acids in human nutrition: report of an expert consultation. Rome. FAO Food and Nutrition Paper 91.

16. Fernandez-Ginés J.M., Fernández-López J., Sayas-Barberá E., Sendra E., Pérez-Álvarez J.A. (2004, May). Lemon albedo as a new source of dietary fiber: Application to bologna sausages. Meat Science, 67, (1), 7-13. Retrieved March 28, 2015, from Science Direct database, Web: http://www.sciencedirect.com. DOI:10.1016/j.meatsci.2003.08.017.

17. Figuerola F., Hurtado M.L., Estevez A.M., Chiffelle I., Asenjo F. (2005, July). Fibre concentrates from apple pomace and citrus peel as potential fibre sources for food enrichment. Food Chemistry, 91 (3), 395-401. Retrieved June 22, 2015, from Science Direct database, Web: http://www.sciencedirect.com. DOI:10.1016/j.foodchem.2004.04.036.

18. Garcia-Iniguez de Ciriano M., Rehecho S., ICalvo M., Cavero R.Y., Navarro I., Astiasaran I., Ansorena D. (2010, June). Effect of lyophilized water extracts of Melissa officinalis on the stability of algae and linseed oil-in-water emulsion to be used as a functional ingredient in meat products. Meat Science, 85, (2), 373377. Retrieved June 22, 2015, from Science Direct database, Web: http://www.sciencedirect.com. DOI:10.1016/j.meatsci.2010.01.007.

19. Garcia-Perez F.J., Sendra E., Lario Y., Fernandez-Lopez J., Sayas-Barbera E., Perez-Alvarez J.A. (2006, January). Rheology of orange fiber enriched yogurt, Milchwissenschaft-Milk, Science International, 61 (1), 55-59. Retrieved June 22, 2015, from Research Gate database, Web: https://www.researchgate.net.

20. Gök Veli, Akkaya Levent, Obuz Ersel , Bulut Sait. (2011, December). Effect of ground poppy seed as a fat replacer on meat burgers. Meat Science, 89, (4), 400-404. Retrieved June 24, 2015, from Science Direct database, Web: http://www.sciencedirect.com. DOI:10.1016/j.meatsci.2011.04.032.

21. Guggisberg D., Cuthbert-Steven J., Piccinah P., Butikofer U., Eberhard P. (2009, February). Rheological, microstructural and sensory characterization of low-fat and whole milk set yoghurt as influenced by inulin addition. International Dairy Journal, 19 (2), 107-115. Retrieved September 20, 2015, from Science Direct database, Web: http://www.sciencedirect.com. DOI:10.1016/j.idairyj.2008.07.009.

22. Hooper L, Abdelhamid A, Moore HJ, Douthwaite W, Skeaff CM, Summerbell CD. (2012, December). Effect of reducing total fat intake on body weight: systematic review and meta-analysis of randomised controlled trials and cohort studies. British Medical Journal; 345: e7666. Retrieved September 7, 2015, from British Medical Journal database, Web: http://www.bmj.com. DOI: 10.1136/bmj.e7666.

23. Huang S.C., Shiau C.Y., Liu T.E, Chu C.L., Hwang D.F. (2005, August). Effects of rice bran on sensory and physico-chemical properties of emulsified pork meatballs. Meat Science, 70, (4), 613-619. Retrieved June 22, 2015, from Science Direct database, Web: http://www.sciencedirect.com. DOI:10.1016/j.meatsci.2005.02.009. 
24. Jonnalagadda S.S., Jones J.M. (2005). ADA reports, Position of the American Dietetic Association: Fat Replacers. Journal of the American Dietetic Association, 105, 266-275.

25. Imaijumi K., Adan Y., Shibata K. (2000). Role of dietary lipids in arteriosclerosis in experimental animals. Biofactors, 13 (1-4), 25-28. Retrieved August 28, 2015, from Wiley Online Library, Web: http://onlinelibrary.wiley.com. DOI:10.1002/biof.5520130105.

26. Kumar SS, Balasubramanian S, Biswas AK, Chatli MK, Devatkal SK, Sahoo J. (2011, August). Efficacy of soy protein isolate as a fat replacer on physicochemical and sensory characteristics of low-fat paneer. Journal of Food Science and Technology, 48, (4), 498-501. Retrieved September 10, 2015, from ProQuest Central, Web: http://search.proquest.com.am.enformation.ro. DOI:http://dx.doi.org/10.1007/s13197-010-0193-z.

27. Lyly M., Liukkonen K.H., Salmenkallio-Marttila M., Karhunen L., Poutanen K., Lahteenmaki L. (2009, June). Fibre in beverages can enhance perceived satiety. European Journal of Nutrition, 48 (4), 251-258. Retrieved September 10, 2015, from ProQuest Central, Web: http://search.proquest.com.am.enformation.ro. DOI:10.1007/s00394-009-0009$\mathrm{y}$.

28. Martínez-Cervera S., A. Salvador, B. Muguerza, L. Moulay, S.M. Fiszman. (2011, April). Cocoa fibre and its application as a fat replacer in chocolate muffins. LWT - Food Science and Technology, 44, (3), 729-736. Retrieved September 20, 2015, from Science Direct database, Web: http://www.sciencedirect.com. DOI:10.1016/j.1wt.2010.06.035.

29. Miles R.S., (1996). Processing of low fat meat products. 49th reciprocal meat conference proceedings, American Meat Science Association, Chicago, IL, pp. $17-22$.

30. Mironescu M., Mironescu I.D., (2011). Design of a knowledge and management system for starch bioconversion, Procedia Food Science, 1, 667670

31. Mironescu I.D., Mironescu M., (2012). Application of a new developed knowledge acquisition and management system for maltodextrins production, Proceedings of the International Conference "Agricultural and Food Sciences, Processes and Technologies" Fifth edition, Sibiu, 377-383, http://saiapm.ulbsibiu.ro/rom/cercetare/conferinte/AFSPT2012/1AFSPT 2012.html

32. O'Connor, T. P., O'Brien, N. M. (2011). Butter and other milk fat products e fat replacers, J. W. Fuquay (Ed.), (pp.528-532). San Diego: Academic Press: Encyclopedia of dairy sciences (2nd ed.).

33. Pinho L. X., Afonso M.R.A, Carioca J.O.B., Costa J.M.C., Ramos A.M. (2010, October). The use of cashew apple residue as source of fiber in low fat hamburgers, Ciênc. Tecnol. Aliment., Campinas, 31,(4), 941-945. Retrieved September 9, 2015, from Research Gate database, Web: https://www.researchgate.net DOI: 10.1590/S0101-20612011000400018.

34. Roland A., Phillips L., Boor K., (1999). Effects of Fat Replacers on the Sensory Properties, Color, Melting, and Hardness of Ice Cream, Journal of Dairy Science 82 (9), 2094-2100. doi:10.3168/jds.S0022-0302(99)75451-2 
35. Romeih EA, Michaelidou A, Biliaderis CG, Zerfiridis GK. (2002). Low fat white-brined cheese made from bovine milk and two commercial fat mimetics: chemical, physical and sensory attributes. International Dairy Journal, 12, (6), 525-540. Retrieved September 23, 2015, from Science Direct database, Web: http://www.sciencedirect.com. doi:10.1016/S0958-6946(02)00043-2.

36. Sahan N., Yasar K., Hayaloglu A.A., Karaca O.B., Kaya A. (2008, February). Influence of fat replacers on chemical composition, proteolysis, texture profiles, meltability and sensory properties of low-fat Kashar cheese. Journal of Dairy Research, 75, 1-7. Retrieved January 20, 2016, from ProQuest Central database, Web: http://search.proquest.com.am.enformation.ro. DOI: 10.1017/S0022029907002786.

37. Santhi D., Kalaikannan A. (2014). The Effect of the Addition of Oat Flour in Low-Fat Chicken Nuggets. Journal of Nutrition \& Food Science, 4, (1), 260. Retrieved January 20, 2016, from ProQuest Central database, Web: http://search.proquest.com.am.enformation.ro. $\quad$ DOI: $\quad 10.4172 / 2155$ 9600.1000260

38. Sendra E., Fayos P., Lario Y., Fernandez-Lopez J., Sayas-Barbera E., PerezAlvarez J.A. (2008, February). Incorporation of citrus fibers in fermented milk containing probiotic bacteria, Food Microbiology, 25 (1), 13-21. Retrieved January 16, 2016, from Science Direct database, Web: http://www.sciencedirect.com. DOI:10.1016/j.fm.2007.09.003.

39. Sendra E., Kuri V., Fernandez-Lopez J., Sayas-Barbera E., Navarro C., PerezAlvarez J.A. (2010, May). Viscoelastic properties of orange fiber enriched yogurt as a function of fiber dose, size and thermal treatment. LWT-Food Science and Technology, 43 (4), 708-714. Retrieved January 16, 2016, from Science Direct database, Web: http://www.sciencedirect.com. DOI:10.1016/j.lwt.2009.12.005.

40. Serrano A., Cofrades S., Ruiz-Capillas C., Olmedilla-Alonso B., HerreroBarbudo C., Jiménez-Colmenero F. (2005, August). Nutritional profile of restructured beef steak with added walnuts. Meat Science, 70, (4), 647-654. Retrieved March 20, 2015, from Science Direct database, Web: http://www.sciencedirect.com. DOI:10.1016/j.meatsci.2005.02.014.

41. Siraj N, Shabbir MA, Ahmad T, Sajjad A, Khan MR, Khan MI, Butt MS. (2015, January). Organogelators as a Saturated Fat Replacer for Structuring Edible Oils. International Journal of Food Properties, 18, (9), 1973 - 1989. Retrieved September 18, 2015, from Taylor and Francis Online database, Web: http://www.tandfonline.com. DOI: 10.1080/10942912.2014.951891.

42. Suzana Caetano da Silva Lannes, Alline Aurea do Amaral. (2015). Low-Fat Foods. In Ayman Hafiz Amer Eissa (Ed). Food Production and Industry, (167185). InTech, Science, Technology and Medicine open access publisher.

43. Valencia I., O'Grady M.N., Ansorena D., Astiasarán I., Kerry J.P. (2008, December). Enhancement of the nutritional status and quality of fresh pork sausages following the addition of linseed oil, fish oil and natural antioxidants. Meat Science, 80, (4), 1046-1054. Retrieved September 18, 2015, from Science Direct database, Web: http://www.sciencedirect.com. DOI:10.1016/j.meatsci.2008.04.024. 
44. Whelan K., Efthymiou L., Judd P.A., Preedy V.R., Taylor M.A. (2006, August). Appetite during consumption of enteral formula as a sole source of nutrition: The effect of supplementing pea-fibre and fructo-oligosaccharides British Journal of Nutrition, 96 (2), 350-356. Retrieved January 7, 2016, from ProQuest Central, Web: http://search.proquest.com.am.enformation.ro. DOI: 10.1079/BJN20061791.

45. Yang H.S., Choi S.G., Jeon J.T., Park G.B., Joo S.T. (2007, February). Textural and sensory properties of low fat pork sausages with added hydrated oatmeal and tofu as texture-modifying agents. Meat Science, 75, (2), 283-289. Retrieved November 21, 2015, from Science Direct database Web: http://www.sciencedirect.com. DOI:10.1016/j.meatsci.2006.07.013.

46. Zhang Tiehua, McCarthy James, Wang Guorong, Liu Yanyan, Guo Mingruo. (2015, April). Physiochemical Properties, Microstructure and Probiotic Survivability of Nonfat Goats' Milk Yogurt Using Heat-Treated Whey Protein Concentrate as Fat Replacer. Journal of Food Science, 80, (4), 788-794. Retrieved September 9, 2015, from Research Gate database, Web: https:/www.researchgate.net.DOI: 10.1111/1750-3841.12834

47. Akoh, C.C., (March 1998). Fat Replacers. Food technology, 52, (3), 47-53. Retrieved March 25, 2015, Web: http://www.ift.org.

48. Bom Frost M, Dijksterhuis G and Martens M. (2001, July-September). Sensory perception of fat in milk. Food Quality and Preference, 12, (5-7), 327-336. Retrieved June 5, 2015, from Science Direct database Web: http://www.sciencedirect.com. DOI:10.1016/S0950-3293(01)00018-0.

49. Vural H., Javidipour I. (2002, June). Replacement of beef fat in frankfurters by interesterified palm, cottonseed, and olive oils. European Food Research and Technology, 214 (6), 465-468. Retrieved March 18, 2015, from Springer Link database, Web: http://link.springer.com.am.enformation.ro. DOI:10.1007/s00217-002-0502-5.

50. Van Hekken, D.L.; Farke, N.Y. (2003, January). Hispanic cheeses: The quest for queso. Food Technology, 57 (1), 32-38. Retrieved April 23, 2015, from Research Gate database, Web: https://www.researchgate.net.

51. Jo C., Son J.H., Son C.B., Byun M.W. (2003, May). Functional properties of raw and cooked pork patties with added irradiated, freeze-dried green tea leaf extract powder during storage at $4{ }^{\circ} \mathrm{C}$. Meat Science, 64, (1), 13-17. Retrieved May 27, 2015, from Science Direct database, Web: http://www.sciencedirect.com. DOI:10.1016/S0309-1740(02)00131-6.

52. Vural H. (2003, August). Effect of replacing beef fat and tail fat with interesterified plant oil on quality characteristics of Turkish semi-dry fermented sausages. European Food Research and Technology, 217 (2), 100-103. Retrieved August 7, 2015, from ProQuest Central, Web: http://search.proquest.com.am.enformation.ro. DOI:10.1007/s00217-003-0727y.

53. Muguerza E., Ansorena D., Astiasaran I. (2003, December). Improvement of nutritional properties of Chorizo de Pamplona by replacement of pork backfat with soy oil, Meat Science, 65, (4), 1361-1367. Retrieved March 20, 2015, 
from Science Direct database, Web: http://www.sciencedirect.com. DOI:10.1016/S0309-1740(03)00058-5.

54. Kayaardi S., Gok V. (2004, January). Effect of replacing beef fat with olive oil on quality characteristics of Turkish soudjouk (sucuk), Meat Science, 66 (1), 249-257. Retrieved March 16, 2015, from Science Direct database, Web: http://www.sciencedirect.com. DOI:10.1016/S0309-1740(03)00098-6.

55. Vural H., Javidipour I., Ozbas O.O. (2004, May). Effects of interesterified vegetable oils and sugarbeet fiber on the quality of frankfurters. Meat Science, 67, (1), 65-72. Retrieved June 2, 2015, from Science Direct database Web: http://www.sciencedirect.com. DOI:10.1016/j.meatsci.2003.09.006.

56. Ansorena D., Astiasaran I., (August 2004). The use of linseed oil improves nutritional quality of the lipid fraction of dry-fermented sausages. Food Chemistry, 87, 69-74. Retrieved August 2, 2015, from Science Direct database Web: http://www.sciencedirect.com. Doi:10.1016/j.foodchem.2003.10.019

57. Serdaroglu, M., Degirmencioglu, O. (2004, October). Effects of fat level 5\%, $10 \%, 20 \%$ and corn flour $0 \%, 2 \%, 4 \%$ on some properties of Turkish type meatballs koefte. Meat Sci.68, (2), 291-296. Retrieved September 26, 2015, from Science Direct database, Web: http://www.sciencedirect.com. DOI:10.1016/j.meatsci.2004.03.010.

58. Madadlou A, Khosrowshahi A, Mosavi M.E. (2005, September). Rheology, microstructure and functionality of low-fat Iranian White cheese made whit different concentration of rennet. Journal of Dairy Science, 88, (9), 3052-3062. Retrieved March 20, 2015, from Science Direct database, Web: http://www.sciencedirect.com. DOI:10.3168/jds.S0022-0302(05)72986-6.

59. Borderías A.J., Sánchez-Alonso I., Pérez-Mateos A. (2005, October). New applications of fibres in foods: Addition of fishery products. Trends in Food Science \& Technology, 16, (10), 458-465. Retrieved June 5, 2015, from Science Direct database, Web: http://www.sciencedirect.com. DOI:10.1016/j.tifs.2005.03.011.

60. Turhan S., Sagir I., Ustun N.S. (2005, October). Utilization of hazelnut pellicle in low-fat beef burgers. Meat Science, 71 (2), 312-316. Retrieved March 20, 2015, from Science Direct database, Web: http://www.sciencedirect.com. DOI:10.1016/j.meatsci.2005.03.027.

61. Everett D.W., McLeod R.E. (2005, November). Interactions of polysaccharide stabilisers with casein aggregates in stirred skim-milk yoghurt. International Dairy Journal, 15 (11), 1175-1183. Retrieved March 27, 2015, from Science Direct database, Web: http://www.sciencedirect.com. DOI:10.1016/j.idairyj.2004.12.004.

62. Kip P., Meyer D., Jellema R.H. (2006, September). Inulins improve sensoric and textural properties of low-fat yoghurts. International Dairy Journal, 16 (9), 1098-1103. Retrieved May 10, 2015, from Science Direct database, Web: http://www.sciencedirect.com. DOI:10.1016/S0309-1740(03)00098-6.

63. Harris P.J., Smith B.G. (2006, December). Plant cell walls and cell-wall polysaccharides: Structures, properties and uses in food products. International Journal of Food Science and Technology, 41, 129-143. Retrieved August 7, 
2015, from Wiley Online Library database, Web: http://onlinelibrary.wiley.com. DOI: 10.1111/j.1365-2621.2006.01470.x.

64. Pelser W.M., Linssen J.P., Legger A., Houben J.H. (2007, January). Lipid oxidation in n -3 fatty acid enriched Dutch style fermented sausages. Meat Science, 75, (1), 1-11. Retrieved May 5, 2015, from Science Direct database, Web: http://www.sciencedirect.com. DOI:10.1016/j.meatsci.2006.06.007.

65. Turhan S., Temiz H., Sagir I. (2007, April). Utilization of wet okara in low-fat beef patties. Journal of Muscle Foods, 18 (2), 226-235. Retrieved August 28, 2015, from Wiley Online Library Web: http://onlinelibrary.wiley.com. DOI:10.1111/j.1745-4573.2007.00081.x.

66. Soukoulis C., Panagiotidis P., Koureli R., Tzia C. (2007, June). Industrial yogurt manufacture: Monitoring of fermentation process and improvement of final product quality. Journal of Dairy Science, 90 (6), 2641-2654. from ProQuest Central, Web: http://search.proquest.com.am.enformation.ro. DOI: 10.3168/jds.2006-802.

67. Oh H.E., Anema S.G., Wong M., Pinder D.N., Hemar Y. (2007, July). Effect of potato starch addition on the acid gelation of milk. International Dairy Journal, 17 (7), 808-815. Retrieved March 20, 2015, from Science Direct database, Web: http://www.sciencedirect.com. DOI:10.1016/j.idairyj.2006.09.013.

68. Rahimi J, Khosrowshahi A, Madadlou A, Aziznia S. (2007, September). Texture of low-fat Iranian white cheese as influenced by gum tragacanth as a fat replacer. Journal of Dairy Science, 90, (9), 4058-4070. . Retrieved March 12, 2015, from ProQuest Central database, Web: http://search.proquest.com.am.enformation.ro. DOI:10.3168/jds.2007-0121.

69. Brennan C.S., Tudorica C. M. (2008, May). Carbohydrate-based fat replacers in the modification of the rheological, textural and sensory quality of yoghurt: comparative study of the utilisation of barley beta-glucan, guar gum and inulin. International Journal of Food Science and Technology, 43, (5), 824-833. Retrieved August, 26, 2015, from Wiley Online Library Web: http://onlinelibrary.wiley.com.DOI:10.1111/j.1365-2621.2007.01522.x

70. Redgwell R.J., Curti D., Gehin-Delval C. (2008, June). Physicochemical properties of cell wall materials from apple, kiwifruit and tomato. European Food Research and Technology, 227 (2), 607-618. Retrieved September 9, 2015, from Springer Link database, Web: http://link.springer.com.am.enformation.ro. DOI:10.1007/s00217-007-0762-1.

71. Totosaus A., Guemes-Vera N. (2008, August). Effect of k- and $\lambda$-carrageenans as fat-replacers in low-fat Oaxaca cheese. International Journal of Food Properties, 11, (3), 656-668. Retrieved June 5, 2015, from Taylor \& Francis Online database, Web: http://www.tandfonline.com. DOI:10.1080/10942910701594111.

72. Chantaro P., Devahastin S., Chiewchan N. (2008, December). Production of antioxidant high dietary fiber powder from carrot peels. LWT-Food Science and Technology, 41 (10), 1987-1994. Retrieved June 5, 2015, from Science Direct database, Web: http://www.sciencedirect.com. DOI:10.1016/j.lwt.2007.11.013.

73. Nishida C, Uauy R. (2009, May). WHO scientific update on health consequences of trans fatty acids: introduction. European Journal of Clinical 
Nutrition. 63 Suppl 2:S1-S4. Retrieved February 9, 2016, from European Journal of Clinical Nutrition database. Web: http://www.nature.com. DOI:10.1038/ejen.2009.13.

74. Sayago-Ayerdi S.G., Brenes A., Goni I. (2009, June). Effect of grape antioxidant dietary fiber on the lipid oxidation of raw and cooked chicken hamburgers. LWT - Food Science and Technology, 42, (5), 971-976. Retrieved May 16, 2015, from Science Direct database, Web: http://www.sciencedirect.com. DOI:10.1016/j.lwt.2008.12.006.

75. Hashim I.B., Khalil A.H., Afifi H.S. (2009, November). Quality characteristics and consumer acceptance of yogurt fortified with date fiber. Journal of Dairy Science, 92 (11), 5403-5407. Retrieved August 7, 2015, from ProQuest Central, Web: http://search.proquest.com.am.enformation.ro. DOI: $10.3168 /$ jds.2009-2234.

76. Ferguson, G.R. (2010, February). Meat and cancer. Meat Science, 84, (2), 308313. Retrieved March 27, 2015, from Science Direct database, Web: http://www.sciencedirect.com. DOI:10.1016/j.meatsci.2009.06.032.

77. Gupta P., Premavalli K.S. (2010, February). Effect of particle size reduction on physicochemical properties of ashgourd (Benincasa hispida) and radish (Raphanus sativus) fibres, International Journal of Food Sciences and Nutrition, 61 (1), 18-28. Retrieved June 5, 2015, from Taylor \& Francis Online database, Web: http://www.tandfonline.com, DOI: 10.3109/09637480903222186.

78. Ertekin B., Guzel-Seydim Z. B. (2010, March). Effect of fat replacers on kefir quality. Journal of the Science of Food and Agriculture; 90, (4), 543-548. Retrieved June 18, 2015, from Research Gate database, Web: https://www.researchgate.net. DOI: 10.1002/jsfa.3855.

79. Pietrasik Z., Janz J.A.M. (2010, March). Utilization of pea flour, starch-rich and fiber-rich fractions in low fat bologna. Food Research International, 43, (2), 602-608. Retrieved September 18, 2015, from Science Direct database, Web: http://www.sciencedirect.com. DOI:10.1016/j.foodres.2009.07.017.

80. Wang, B., Li, D., Wang, L. J., \& Özkan, N. (2010, March). Anti-thixotropic properties of waxy maize starch dispersions with different pasting conditions. Carbohydrate Polymers, 79, (4), 1130-1139. Retrieved October 25, 2015, from Science Direct database Web: http://www.sciencedirect.com. DOI:10.1016/j.carbpol.2009.10.053.

81. Day L., Xu M., Oiseth S.K., Lundin L., Hemar Y. (2010, December). Dynamic rheological properties of plant cell wall particle dispersions. Colloids and Surfaces B: Biointerfaces, 81, (2), 461-467. Retrieved June 7, 2015, from Science Direct database, Web: http://www.sciencedirect.com. DOI:10.1016/j.colsurfb.2010.07.041.

82. McCann Thu H., Florence Fabre, Li Day. (2011, May). Microstructure, rheology and storage stability of low-fat yoghurt structured by carrot cell wall particles, Food Research International, 44, (4), 884-892. Retrieved January 12, 2016, from Science Direct database, Web: http://www.sciencedirect.com. DOI:10.1016/j.foodres.2011.01.045. 
83. Rodríguez-Carpena J.G., Morcuende D., Estévez M. (2011, October). Avocado by-products as inhibitors of color deterioration and lipid and protein oxidation in raw porcine patties subjected to chilled storage, Meat Science, 89, (2), 166173. Retrieved September 23, 2015, from Science Direct database, Web: http://www.sciencedirect.com. DOI:10.1016/j.meatsci.2011.04.013.

84. Tabarestani H S, Tehrani M M. (2014, February). Optimization of physicochemical properties of low-fat hamburger formulation using blend of soy flour, split-pea flour and wheat starch as part of fat replacer system. Journal of Food Processing and Preservation, 38, (1), 278-288. Retrieved August 28, 2015, from Wiley Online Library Web: http://onlinelibrary.wiley.com.DOI: 10.1111/j.1745-4549.2012.00774.x.

85. Akin M.S., Kirmaci Z. (2014, August). Influence of fat replacers on the chemical, textural and sensory properties of low-fat Beyaz pickled cheese produced from ewe's milk. International Journal of Dairy Technology, Vol 68, (1), 127-135. Retrieved August 28, 2015, from Wiley Online Library Web: http://onlinelibrary.wiley.com. DOI: 10.1111/1471-0307.12164.

86. Hygreeva D., Pandey M.C., Radhakrishna K. (2014, September). Potential applications of plant based derivatives as fat replacers, antioxidants and antimicrobials in fresh and processed meat products, Meat Science, 98, (1), 4757. Retrieved March 16, 2015, from Science Direct database, Web: http://www.sciencedirect.com. DOI:10.1016/j.meatsci.2014.04.006.

87. Chugh B., Singh G., Kumbhar B. K. (2015, January). Studies on the Optimization and Stability of Low-Fat Biscuit Using Carbohydrate-Based Fat Replacers, International Journal of Food Properties, 18:1446-1459. Retrieved June 5, 2015, from Taylor \& Francis Online database, Web: http://www.tandfonline.com, DOI:10.1080/10942912.2013.833218.

88. Namir Mohammad, Hassan Siliha, Mohamed Fawzy Ramadan. (2015, September). Fiber pectin from tomato pomace: characteristics, functional properties and application in low-fat beef burger. Food Measure, 9, (3), 305312. Retrieved September 9, 2015, from Springer Link database, Web: http://link.springer.com.am.enformation.ro. DOI: 10.1007/s11694-015-9236-5. 